\title{
Effect of Amla (Emblica officinalis) on the Hematology and Serum Biochemical Parameters of Rohu Fingerlings in Tarai Conditions of Uttarakhand, India
}

\author{
Mahima Tamta* and Amita Saxena \\ Department of Fisheries Resource Management, College of Fisheries, G.B.P.U.A. \& T., \\ Pantnagar, India \\ *Corresponding author
}

\begin{abstract}
A B S T R A C T
Keywords

Vitamin C, Emblica officinalis, Carps,

hematology, Serum biochemical parameters

Article Info

Accepted: 15 September 2018 Available Online: 10 October 2018

Emblica officinalis, is also known as amla, has been used in Ayurveda, the ancient system of Indian medicine. Amla has been used for curing many disorders such as common cold, scurvy, cancer and heart diseases in humans. It is supposed that the major factor responsible for all these curing activities is Vitamin $\mathrm{C}$ (Ascorbic acid), which is contained in large proportion in the pulp of amla. The present study was conducted to study the effect of different concentrations of amla as a feed additive on the hematology and serum biochemical parameters of Rohu (Labeo rohita) fingerlings. Four experimental diets, T0, T1, T2 and T3, were prepared with dried amla powder as a feed additive mixed @ $0 \%$ (Control), 1\%, 5\% and 10\% of feed, respectively. The results showed that the haematological and serum biochemical parameters were better in all the fishes fed with T3 ( $10 \%$ dried amla per $\mathrm{kg}$ feed) in respect to length, weight, F.C.R., F.C.E., S.G.R., condition factor, survival rate and weight gain. All the results obtained were also statistically checked and found to be significant $(P>0.05)$.
\end{abstract}

\section{Introduction}

The goal of the fisheries industry is to optimize the growth and to produce quality fish but the diseases outbreak in fish farming is a major concern, the high vulnerability of fish to stress and the diseases have forced fish farmers to shift their focus towards maintaining the fish against infectious disease, so that they can achieve sustainable economic performances. In order to rectify this problem the use of immune-stimulants is an easy tool the use of which can enhance activities in the nonspecific defence mechanism, increase resistance to infectious disease by enhancing inherent humoral and cellular defense mechanisms and ultimately enhance growth and overall improvement in fish. In this respect, vitamins prove to be one of the major immune-stimulants with special importance in modulating the immune system of fish.

Vitamins are organic substances that are essential for growth and maintenance of animals, but they are required in small extent. As fish is unable to synthesize vitamins at all or can only synthesize them in inadequate quantities for basic development, growth and 
maintenance, they must be supplied by means of the diet (Falahatkar et al., 2011).

Antioxidant L-ascorbic acid (vitamin C) is an important vitamin for growth and physiological function in fish. It plays a considerable role in the growth, collagen formation, iron metabolism haematology, reproduction response to stressors, wound healing and immune response. Adequate quantity of ascorbic acid in fish diet, predominantly in early life stages, plays a vital role in disease resistance followed by fish immunity and survival.

Majority of the teleosts are incapable to synthesize vitamin $\mathrm{C}$ from $\mathrm{D}$-glucose due to the lack of L-gluconolactone oxidase which is responsible for synthesis of antioxidant vitamin $\mathrm{C}$ (de novo). Therefore, a supplementary source of antioxidant vitamin $\mathrm{C}$ is obligatory in fish diet. However, ascorbic acid need is inconsistent among diverse aquatic species and is dependent on fish size, diet composition, and cultural system (Ai et al., 2004; Garcia et al., 2007).

Blood is a liquid tissue which comprises of plasma, erythrocytes, leukocytes and thrombocytes and is enclosed within the cardiovascular system. It comprises 1.3 to $7 \%$ of the total body weight of fishes and is one of the most active constituents that contribute to the metabolic course of actions by ensuring gas exchange within the body and between the fish and surroundings. Any dysfunction of the blood can have severe impacts on the physiological processes of fish. The most important role of blood in fishes as in other vertebrates also is the transportation of oxygen and nutrition to tissues, maintenance of acidbase balance, and removal of metabolic waste products from tissues etc. Hematological studies had been used as an efficient and sensitive index to monitor physiological and pathological changes in fish.
Emblica officinalis, is also known as Phyllanthus emblica or amla, has been used in Ayurveda, the ancient system of Indian medicine. Amla has been used for curing many disorders such as common cold, scurvy, cancer and heart diseases. It is supposed that the major factor responsible for all these curing activities is Vitamin C (Ascorbic acid), which is contained in large proportion in the pulp of amla. Amla has various properties viz. antioxidant, anti-inflammatory, antimutagenic, anti-fungal and antimicrobial activity (Ihantola-Vormisto et al., 1997: Bhattacharya and Ghosal 2000; Khopde et al., 2001).

Based on these facts and studies, the present study was conducted to study the effect of different concentrations of amla as a feed additive on the hematology and serum biochemical parameters of fingerlings of Labeo rohita. Seeing the importance and all the qualities of amla, fruit pulp was incorporated in the diet of fish fingerlings.

\section{Materials and Methods}

The present research work was conducted to estimate the effect of amla as a feed additive used in different concentrations on the haematology and serum biochemical parameters of the experimental fish fingerlings.

\section{Experimental site}

The experiment was conducted at College of Fisheries, Pantnagar, geographically located at $29^{\circ} \mathrm{N}$ latitude, 79.3 degree longitude and an altitude of $243.3 \mathrm{~m}$ above mean sea level (MSL), in Tarai belt of Shivalik range of Himalaya.

The site had humid sub-tropical climate characterized by very hot and dry summer and very cold winter. 


\section{Experimental fish and setup}

The experimental fish fingerlings were collected during the month of March 2017 from fish seed hatchery of College of Fisheries and kept in F.R.P. tanks in wet laboratory of the college. The carp species selected for the experiment had the same length and weight. The experiment was setup in triplicates with four feeding groups.

\section{Feed Formulation and feeding schedule}

The feed for fish fingerlings was prepared with three basal ingredients i.e. rice bran, mustard oil cake, and soyabean oil cake, in the ratio of 1:1:1 along with little amount of wheat flour as binder, 1\% Agrimin Forte (vitaminmineral mixture) and vitamin $\mathrm{E}$ powder was also mixed in the feed that was put constant (5 gm per kg feed) in all the experimental feeds.

Four experimental diets, T0, T1, T2 and T3, were prepared with dried amla powder as a feed additive mixed @ 0\% (Control), 1\%,5\% and $10 \%$ of feed, respectively. The proximate composition of basal feed i.e., moisture content, crude protein level, crude fat level and ash, was also calculated prior the starting of experiment. Feeding was done @ 6\% of average body weight of fingerlings twice a day.

\section{Feed ingredient analysis and feed formulation}

The nutritional status of feed in fishes is important in determining the ability of fish to resist various diseases. Therefore, there is a clear need for a proper diet to improve the health and to prevent the outbreaks of disease. Fish growth and survival are primary key factors for successful development of aquaculture practices. The growth enhancers are non-nutritive compounds, which at very low levels of supplementation in the feed enhance growth and feed efficiency (Viola and Arieli, 1987).

The basal feed ingredients for the feed formulation were collected from the feed mill of College of Fisheries Govind Ballabh Pant University of Agriculture and Technology, Pantnagar, Udham Singh Nagar, Uttarakhand India. The feed for fish fingerlings was prepared with three basal ingredients i.e. rice bran, mustard oil cake, and soyabean oil cake, in the ratio of $1: 1: 1$.

\section{Collection of amla}

The amla fruit was purchased from local market (Haat) of pantnagar. The fruit was divided into small pieces and then shade dried. After drying the fruit was grinded using ball mixture. Amla powder was then stored in sealed plastic boxes at room temperature and was kept away from the sun light and heat.

\section{Results and Discussion}

\section{Proximate composition of feed}

Proximate composition of feed was calculated and values were found to be as given in Table 1.

\section{Hematological parameters}

The mean value of haemoglobin for T0 i.e. the control group was $\mu=9.05( \pm 0.88) \mathrm{mg} \%$, and coefficient of variation (CV) was $9.70 \mathrm{mg} \%$, in treatment $\mathrm{T} 1$ the $\mu$ was 9.07 and $\mathrm{CV}$ was $9.85( \pm 0.89)$, in treatment $\mathrm{T} 2$ the $\mu$ was 9.12 $( \pm 0.92) \mathrm{mg} \%$ and $\mathrm{CV}$ was 10.0 , and for treatment $\mathrm{T} 3$ the mean value of haemoglobin was $9.17( \pm 0.93) \mathrm{mg} \%$. As the amount of amla powder (vitamin C) was increased the mean $\mathrm{Hb}$ content was almost equal but there is a variation $\mathrm{CV}$ increased. The average value of total leucocytes count was $8.05 \quad( \pm 0.43)$ $\mathrm{x} 10^{3} / \mathrm{mm}$ in treatment $\mathrm{T} 2$, and the highest 
value was obtained in treatment T3 i.e. 8.12 $( \pm 0.53) \times 10^{3} / \mathrm{mm}$. The average value of Total erythrocyte count was lowest $2.03( \pm 0.26)$ $\mathrm{x} 10^{6} / \mathrm{mm}$ in fingerlings fed with the control diet, and highest value of TEC was recorded in treatment T3 i.e. $2.09( \pm 0.29) \times 10^{6} / \mathrm{mm}$, which clearly indicated that with the elevating amount of vitamin $\mathrm{C}$ in the diet of fingerlings the erythrocyte count was also increasing.

\section{Serum biochemical parameters}

When serum biochemical parameters were estimated it was found that the lowest values of total protein, albumin and globulin recorded in the fingerlings that were fed with the control diet. The value of total protein in control group was $2.47( \pm 0.11) \mathrm{g} / \mathrm{dl}$ and the highest value was obtained in the T3 group i.e. $2.52( \pm 0.15) \mathrm{g} / \mathrm{dl}$. Albumin was lowest in the control group i.e. $1.32( \pm 0.07) \mathrm{g} / \mathrm{dl}$, and the highest value of albumin was recorded in T3 group, and it was $1.35( \pm 0.08) \mathrm{g} / \mathrm{dl}$. The amount of globulin followed the same trend, it was also lowest in the fingerlings of Rohu that were fed with the control diet, it is 1.15 $( \pm 0.04) \mathrm{g} / \mathrm{dl}$, and the highest value of globulin was recorded in the T3 group, i.e.1.17 $( \pm 0.06)$ $\mathrm{g} / \mathrm{dl}$. When the amount of serum creatinine was estimated it was found that the lowest average value of serum creatinine was obtained in group T3 i.e. $0.49( \pm 0.02) \mathrm{g} / \mathrm{dl}$ and the highest value of serum creatinine was recorded in the group of fingerlings that were fed with control diet i.e. $0.53( \pm 0.04) \mathrm{g} / \mathrm{dl}$. The reason behind this was that serum creatinine is the muscle metabolic product which is not good for the renal health. The amount of serum creatinine is the indicator of renal health. Kidneys played a significant role in filtering out this metabolic waste out of the body, so in present study the lower amount of serum creatinine in fingerlings of treatment $\mathrm{T} 3$ clearly indicated that vitamin $\mathrm{C}$ had the positive effect on renal system of fish.

The proximate composition of formulated feed was analysed and the amount of moisture found was $10.09 \%$, protein content $28.70 \%$, fat content $7.56 \%$, carbohydrate $46.65 \%$, and ash content was $7.00 \%$. The haematological parameters such as haemoglobin percent, total leukocyte count, total erythrocyte count, were best obtained by the fingerlings those were fed with the highest amount of vitamin C.

Mean value $(\mu)$ of haemoglobin for T0 i.e. the control group was $\mu=9.05( \pm 0.88)$ $\mathrm{mg} \%$, and coefficient of variation (CV) was $9.70 \mathrm{mg} \%$, in treatment $\mathrm{T} 1$ the $\mu$ was 9.07 and $\mathrm{CV}$ was $9.85( \pm 0.89)$, in treatment $\mathrm{T} 2$ the $\mu$ was $9.12( \pm 0.92) \mathrm{mg} \%$ and $\mathrm{CV}$ was 10.0 , and for treatment T3 the mean value of haemoglobin was $9.17( \pm 0.93) \mathrm{mg} \%$. As the amount of amla powder (vitamin C) was increased the mean $\mathrm{Hb}$ content was almost equal but there is a variation CV increased. The average value of total leucocytes count was $8.05( \pm 0.43) \times 10^{3} / \mathrm{mm}$ in treatment $\mathrm{T} 2$, and the highest value was obtained in treatment T3 i.e. $8.12( \pm 0.53) \times 10^{3} / \mathrm{mm}$ (Fig. $1-7)$.

Table.1 Proximate composition of feed

\begin{tabular}{|c|c|c|}
\hline S. No. & Contents & Percentage \% \\
\hline $\mathbf{1}$ & Moisture & 10.09 \\
\hline $\mathbf{2}$ & Ash & 7.0 \\
\hline $\mathbf{3}$ & Crude protein & 28.7 \\
\hline $\mathbf{4}$ & Crude fat & 7.56 \\
\hline $\mathbf{5}$ & carbohydrate & 46.65 \\
\hline
\end{tabular}




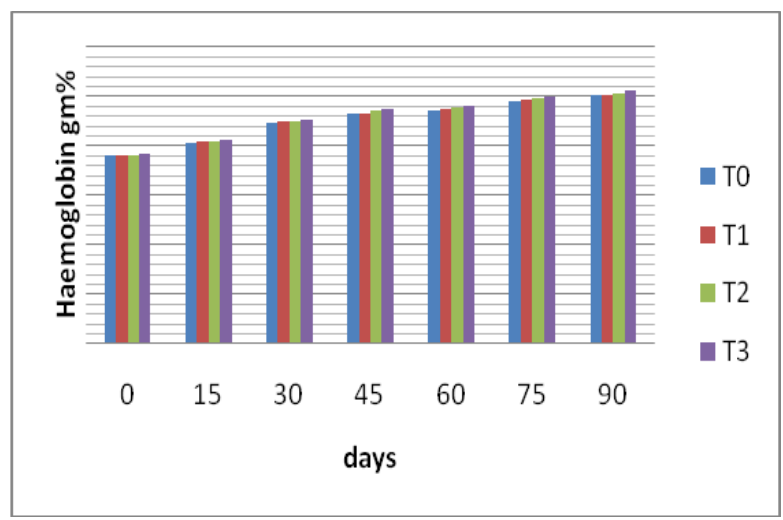

Fig No : 1 Haemoglobin content

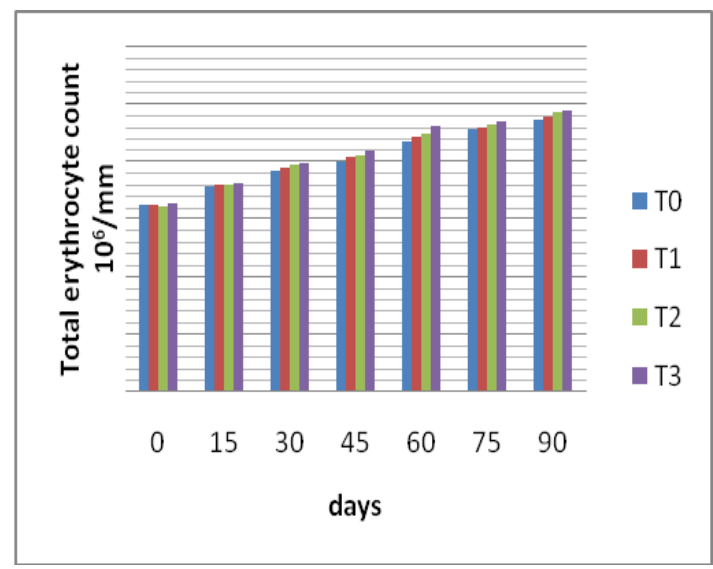

Fig No : 3 Total erythrocyte count

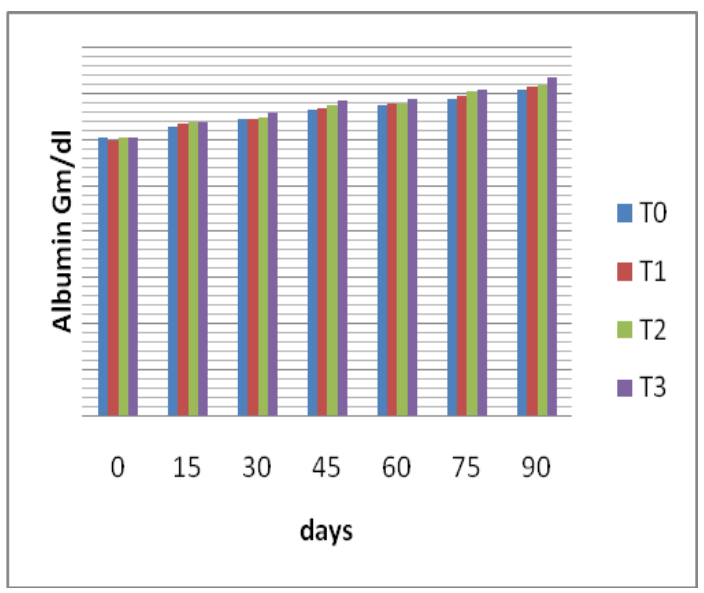

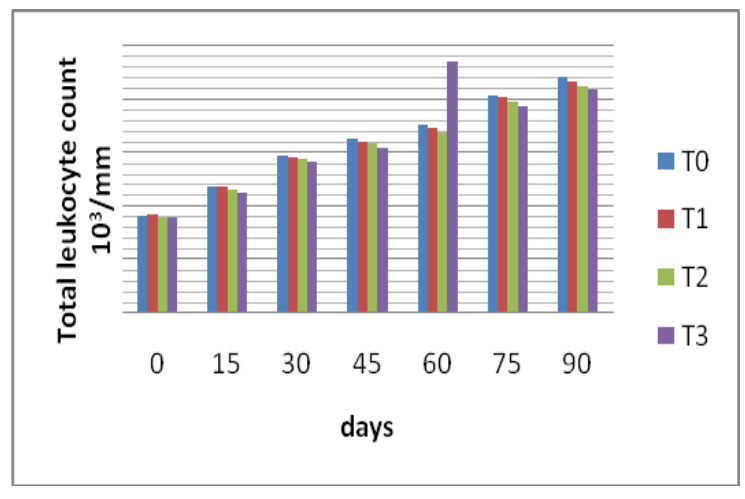

Fig No : 2 Total leukocyte count

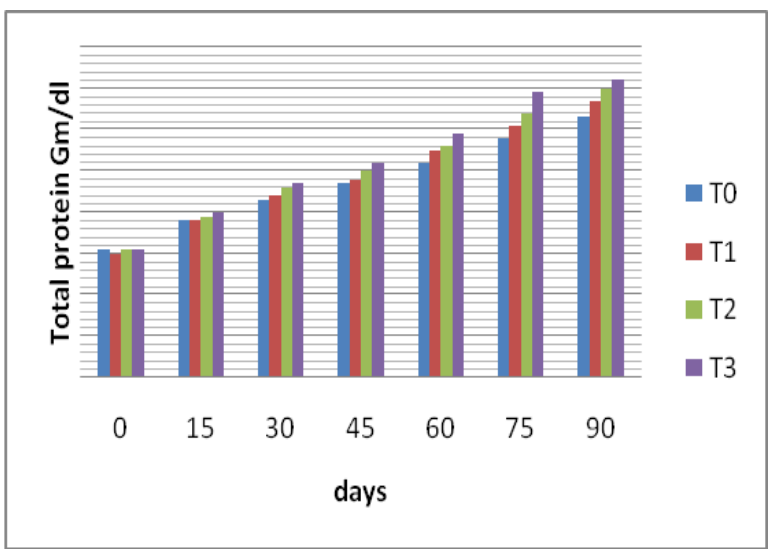

Fig No : 4 Total protein content

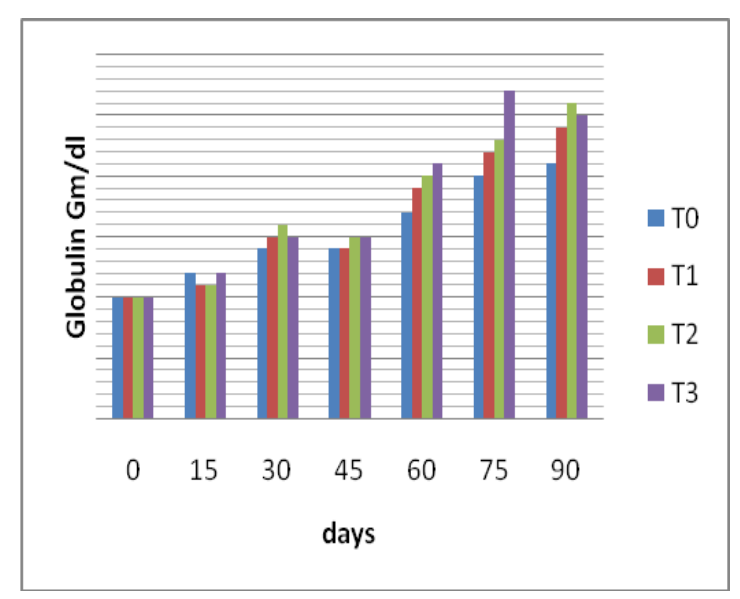


Fig.7 Serum creatinine

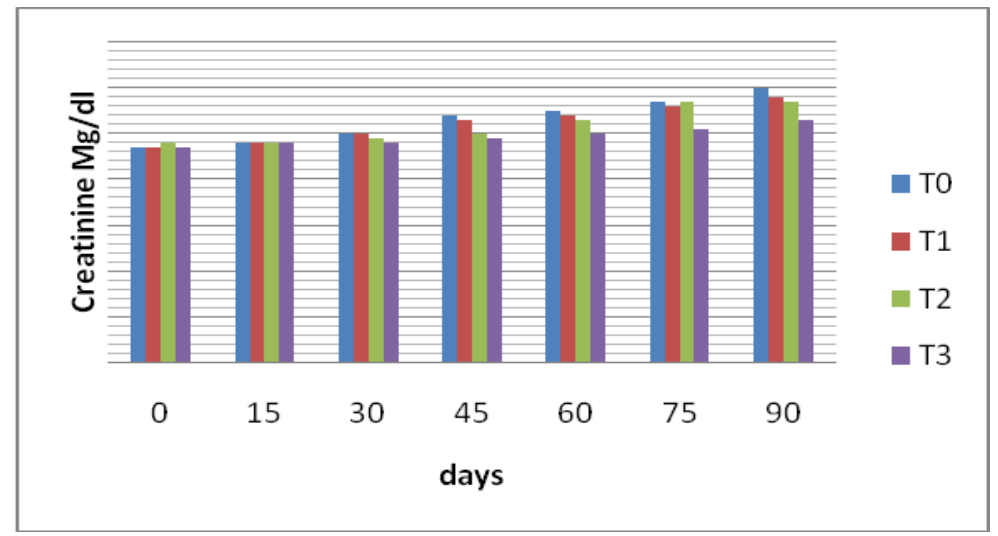

The average value of Total erythrocyte count was lowest $2.03 \quad \pm 0.26) \times 10^{6} / \mathrm{mm}$ in fingerlings fed with the control diet, and highest value of TEC was recorded in treatment T3 i.e. $2.09( \pm 0.29) \times 10^{6} / \mathrm{mm}$, which clearly indicated that with the elevating amount of vitamin $\mathrm{C}$ in the diet of fingerlings the erythrocyte count was also increasing. When serum biochemical parameters were estimated it was found that the lowest values of total protein, albumin and globulin recorded in the fingerlings that were fed with the control diet. The value of total protein in control group was $2.47( \pm 0.11) \mathrm{g} / \mathrm{dl}$ and the highest value was obtained in the T3 group i.e. $2.52( \pm 0.15) \mathrm{g} / \mathrm{dl}$. Albumin was lowest in the control group i.e. $1.32( \pm 0.07) \mathrm{g} / \mathrm{dl}$, and the highest value of albumin was recorded in T3 group, and it was $1.35( \pm 0.08) \mathrm{g} / \mathrm{dl}$. The amount of globulin followed the same trend, it was also lowest in the fingerlings of Rohu that were fed with the control diet, it is $1.15( \pm 0.04) \mathrm{g} / \mathrm{dl}$, and the highest value of globulin was recorded in the T3 group, i.e.1.17 $( \pm 0.06) \mathrm{g} / \mathrm{dl}$. When the amount of serum creatinine was estimated it was found that the lowest average value of serum creatinine was obtained in group T3 i.e. 0.49 $( \pm 0.02) \mathrm{g} / \mathrm{dl}$ and the highest value of serum creatinine was recorded in the group of fingerlings that were fed with control diet i.e. $0.53( \pm 0.04) \mathrm{g} / \mathrm{dl}$. The reason behind this was that serum creatinine is the muscle metabolic product which is not good for the renal health. The amount of serum creatinine is the indicator of renal health. Kidneys played a significant role in filtering out this metabolic waste out of the body, so in present study the lower amount of serum creatinine in fingerlings of treatment T3 clearly indicated that vitamin $\mathrm{C}$ had the positive effect on renal system of fish. The result of the present study was supported by the result of Miar et al., (2013) who observed in rainbow trout that significantly higher RBCs was in diets, 5 (Extruded diet with $50 \mathrm{mg} \mathrm{kg} 1$ $\mathrm{VC}$ and $50 \mathrm{mg} \mathrm{kg} 1 \mathrm{VE}$ ) and 6 6(Extruded diet with $100 \mathrm{mg} \mathrm{kg} 1 \mathrm{VC}$ and $100 \mathrm{mg} \mathrm{kg} 1 \mathrm{VE}$ ) with diet 7 Control (only Extruded diet) $(\mathrm{P}<0.05)$. Pimpimol et al., (2012) reported in Mekong Giant Catfish (Pangasianodon gigas) that the catfish received 500 and $750 \mathrm{mg}$ vitamin $\mathrm{C} \mathrm{kg-1}$ supplementary diets showed the best records of haematocrit, red blood cell count, serum lysozyme, serum protein and serum glucose.

Antioxidant vitamin $\mathrm{C}$ and $\mathrm{E}$ helped in elevation of haemoglobin and other haematological parameters, in maintaining fingerlings showed healthiness in all experimental fish fingerlings. The amount of total protein, albumin, globulin, was also increased with increasing amount of vitamin $\mathrm{C}$, but the there was a declining trend in the values of serum creatinine. The amount of serum creatinine was greater in control group, and it was gradually decreased with increasing level of vitamin C. Because amount of serum creatinine reflects the renal health, low amount 
of serum creatinine is good for proper functioning of kidney, so it was revealed from the above study that antioxidant vitamin $\mathrm{C}$ and $\mathrm{E}$ exerted a positive effect on renal functioning.

Thus, it is concluded that the $100 \mathrm{gm}$ amla powder with antioxidant Vitamin C (1000 mg), and $\mathrm{E}$ at $5 \mathrm{gm}$ per $\mathrm{kg}$ feed were added in the feed gave to fish fingerlings in order to obtain high growth performance and a good health condition of fish.

\section{References}

Ai, Q., Mai, K., Zhang, C., Xu, W., Duan, Q., Tan, B. and Liufu, Z., 2004. Effects of dietary vitamin $\mathrm{C}$ on growth and immune response of Japanese seabass, Lateolabrax japonicus. Aquaculture, 242(1).

Asaikkutti, A., Bhavan, P.S., Vimala, K. and Karthik, M. 2015. Effect of Different Levels of Dietary Vitamin C on Growth Performance, Muscle Composition, Antioxidant and Enzyme Activity of Macrobrachium rosenbergii. Proceedings of the National Academy of Sciences, India Section B: Biological Sciences: 1-10.

Bhattacharya, A., Ghosal, S. and Bhattacharya, S.K., 2000. Antioxidant activity of tannoid principles of Emblica officinalis (amla) in chronic stress induced changes in rat brain.

Falahatkar, B., Dabrowski, K. and Arslan, M., 2011. Ascorbic acid turnover in rainbow trout, Oncorhynchus mykiss: Is there a vitamin enrichment effect during embryonic period on the juvenile fish "sensitivity" to deficiency? Aquaculture, 320(1): 99-105.

Fao, W.F.P., 2012. IFAD. 2012. The state of food insecurity in the world.1-63.

Faramarzi, M., 2012. Effect of dietary vitamin C on growth and feeding parameters, carcass composition and survival rate of Common
Carp (Cyprinus carpio). Global Veterin, 8: 507-510.

Garcia, F., Pilarski, F., Onaka, E.M., de Moraes, F.R. and Martins, M.L., 2007. Hematology of Piaractus mesopotamicus fed diets supplemented with vitamins $\mathrm{C}$ and $\mathrm{E}$, challenged by Aeromonas hydrophila. Aquaculture, 271(1): 39-46.

Ihantola-Vormisto, A., Summanen, J., Kankaanranta, H., Vuorela, H., Asmawi, Z.M. and Moilanen, E., 1997. Antiinflammatory activity of extracts from leaves of Phyllanthus emblica. Planta Medica, 63(06): 518-524.

Khopde, S.M., Priyadarsini, K.I., Guha, S.N. and Mukherjee, T., 2001. Hydroxyl radical induced oxidation of 3-methoxy4-hydroxy cinnamic acid (ferulic acid). Research on Chemical Intermediates, 27(4-5): 519-527.

Miar, A., Matinfar, A., Shamsaei, M. and Soltani, M., 2013. Effects of different dietary vitamin $\mathrm{c}$ and $\mathrm{e}$ levels on growth performance and hematological parameters in rainbow trout (Oncorhynchus mykiss). World Journal of Fish and Marine Sciences, 5(2):220-226.

Pal, H. and Chakrabarty, D., 2012. Evaluations of body composition and growth performance by applying different dietary vitamin $\mathrm{C}$ levels in stinging catfish, Heteropneustes fossilis (Bloch, 1792). Int. J. Pharm. Biol. Sci, 2:193-200.

Pimpimol, T., Phoonsamran, K. and Chitmanat, C., 2012. Effect of Dietary Vitamin C Supplementation on the Blood Parameters of Mekong Giant Catfish (Pangasianodon gigas). International Journal of Agriculture \& Biology, 14(2).

Viola, S. and Arieli, Y., 1987. Non hormonal growth promoters for tilapia and carp. 1. Screening-tests in cages. Bamidgeh, 39(2): 31-38.

\section{How to cite this article:}

Mahima Tamta and Amita Saxena 2018. Effect of Amla (Emblica officinalis) on the Hematology and Serum Biochemical Parameters of Rohu Fingerlings in Tarai Conditions of Uttarakhand, India. Int.J.Curr.Microbiol.App.Sci. 7(10): 2188-2194. doi: https://doi.org/10.20546/ijcmas.2018.710.251 